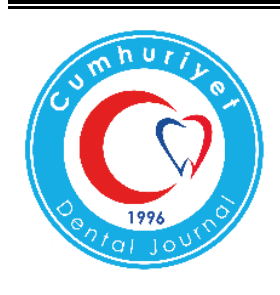

\title{
ASSESSMENT OF BUCCAL BONE THICKNESS IN THE ANTERIOR MAXILLA: A CONE BEAM COMPUTED TOMOGRAPHY STUDY
}

\begin{abstract}
Objectives: The aim of this study was to evaluate buccal bone thickness by cone beam computed tomography (CBCT) in patients in both genders and in different age groups.
\end{abstract}

Materials and Methods: Our study included 186 anterior teeth and 62 patients with CBCT images. Buccal bone thickness was measured at the crest level, and at a distance 1 and $2 \mathrm{~mm}$ apical to the crest level. The t-test and ANOVA test were used in analyzing data.

Results: It was found out that age and gender were not significantly associated with the buccal bone thickness of anterior teeth ( $>>0.05$ ). The mean buccal bone thickness was the highest as $1.91 \mathrm{~mm}$ around the right canines and it was the lowest as $0.35 \mathrm{~mm}$ surrounding the right lateral incisor.

Conclusions: Our study demonstrated that the mean buccal bone thickness increased towards the apical region for all three teeth types. CBCT precisely measures the maxillary bone thickness and may facilitate the planning process for placing implants and scheduling other types of surgeries correctly.

Keywords: Alveolar bone loss, cone-beam computed tomography, maxilla

\author{
*Alaettin Koç ${ }^{1}$, \\ (Didiris Kavut ${ }^{2}$, \\ (D)Mehmet Uğur²
}

ORCID IDs of the authors: A.K.0000-0001-9984-6900 İ.K.0000-0003-2033-4676 M.U.0000-0003-0019-7811

1 Department of Oral and Maxillofacial Radiology, Faculty of Dentistry, Van Yüzüncü Y11 University, Van, Turkey

2 Department of Prosthetic Dentistry, Faculty of Dentistry, Van Yüzüncü Y1l University, Van, Turkey

\footnotetext{
How to Cite: Koç A, Kavut İ, Uğur M. Assessment of Buccal Bone Thickness in The Anterior Maxilla: A Cone Beam Computed Tomography Study. Cumhuriyet Dent J 2019;22:1:102-107. 


\section{INTRODUCTION}

The alveolar process is located adjacent to periodontal ligament, supporting teeth eruption continuously from the cortical layer to all the way to the bone. Facial and lingual/palatal aspects of the alveolar process may depend on the root dimension, angle, and location of erupting teeth. ${ }^{1}$ The alveolar bone displays a physiological remodeling response to external forces. The remodeling process occurs in the periodontal ligament, in the periosteum of the buccal and lingual cortex, and in the endosteal surface of the bone marrow. ${ }^{2}$

Alveolar bone remodeling is controlled by local and systemic factors. Local effects include functional requirements of the tooth and agerelated changes in osteocytes. Systemic effects are controlled by hormones (e.g. parathyroid hormone, calcitonin, and vitamin D). ${ }^{2}$ Osteopetrosis may develop due to age-related hormonal changes; however, the mechanism of these effects on the jaw has not been clarified yet. It was reported that the duration of implant survival was not related to menopause or agerelated osteoporosis. ${ }^{3}$ Physiological or pathological resorption of the alveolar bone is an important problem, complicating the dental rehabilitation process. ${ }^{4}$ Deformities and defects in the tissue can develop; resulting from periodontal diseases, traumas, developmental alveolar clefts, odontogenic cysts, and tumors. ${ }^{5}$

Cone-beam computed tomography (CBCT) provides detailed images of the bone in order to evaluate diseases of the jaw, dentition, and the structure of the facial bones, nasal cavity, and sinuses. Compared to conventional computed tomography (CT) technique, it does not provide diagnostic information of soft tissue structures such as muscles, lymph nodes, glands, and nerves; however, CBCT has the advantage of exposure to lower levels of radiation. ${ }^{6}$

Several studies in the literature have reported that dimensions of the alveolar crest are subject to changes after tooth extraction. Following the completion of the healing process of the alveolar crest, bone loss of the marginal segment becomes more apparent at the facial aspect compared to the marginal bone loss at the lingual/palatal aspect. The observed differences in the quantified healing outcomes may be related to the presence of a thinner layer of bone at the buccal aspect compared to its palatal equivalent. The clinical consequences of bone loss at the buccal aspect may be critical since they may complicate implant placing and restorative aesthetics. ${ }^{7}$

Previously, it was believed that immediate implant placement could alleviate buccal bone resorption and help maintain the original shape of an extraction socket. ${ }^{8}$ However, it has been observed that when an implant is placed immediately, gingival recession occurs leading to aesthetic impairments in patients with thin layers of bone in the buccal region. It is recognized that there should be at least one millimeter of healthy buccal bone layer present so that the aesthetic appearance would be sustained fairly after an immediate implant placement. ${ }^{9}$

In this present study, the thickness of buccal bone layers of anterior teeth from individuals in various age groups and in either gender was compared and the mean values of buccal bone thicknesses were evaluated.

\section{MATERIALS AND METHODS}

The present study was conducted in the Department of Oral and Maxillofacial Radiology after obtaining the approval of the respective Ethics Committee. CBCT images of a total of 186 anterior teeth belonging to 29 males and 33 females in the age range from 19 to 60 years were included in the study. Buccal bone thicknesses of the included teeth were measured on sagittal sectional images in CBCT at the crest level, and at distances 1 and $2 \mathrm{~mm}$ apical from the crest level (Figure 1). The patients with excessive alveolar bone loss, apical pathologies, and CBCT images with inadequate quality were excluded. 


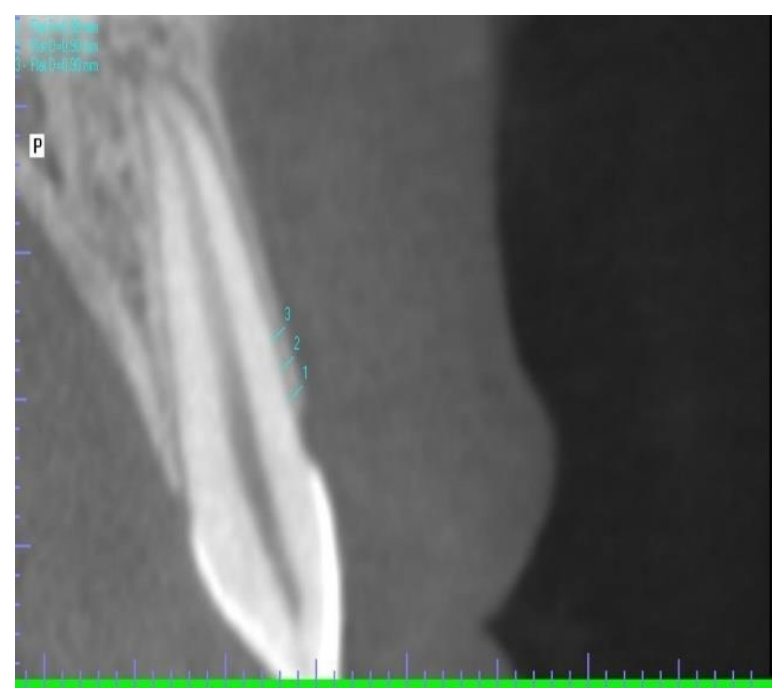

Figure 1. Measurement of buccal bone thickness on sectional CBCT image

The CBCT images of patients were acquired by means of a KaVo 3D eXam (Biberach, Germany) tomography device. The eXamVision (KaVo Dental GmbH, Biberach, Germany) software was used to analyze the acquired images. All measurements were performed by the same investigator, experienced in analyzing $\mathrm{CBCT}$ images for three years. The evaluation process of the CBCT images was performed in the consecutive order of the central incisor, lateral incisor, and canine teeth on the right side.

In order to evaluate the intra-rater reliability, the intraclass correlation coefficient (ICC) value was estimated by measuring the buccal thickness of randomly selected 51 anterior teeth at the crest level, and at distances 1 and $2 \mathrm{~mm}$ apical from the crest level twice in a one-month interval.

SPSS (IBM SPSS Statistics 20.0; IBM Co., Armonk, NY, USA) software was used for the statistical analysis of the collected data. The student's t-test and one-way ANOVA test were used for data analysis. The study was conducted at the significance level of $p<0.05$. The ICC value was used to assess intra-rater reliability.

\section{RESULTS}

The thinnest buccal bone layer was $0.32 \mathrm{~mm}$ at the 2 $\mathrm{mm}$ apical distance from the crest level of the right lateral incisor, and the thickest bone layer was 2.07 $\mathrm{mm}$ at the $2 \mathrm{~mm}$ apical distance from the crest level of the right canine. Comparison of the age groups revealed that the lowest mean thickness of the bone layer was $0.35 \mathrm{~mm}$ surrounding the right lateral incisor in the 30-49-year-age group and the highest of this value was $1.91 \mathrm{~mm}$ around the right canine in the 30-49-year-age group. Furthermore, we found out that the mean thickness of bone gradually increased towards the apical region associated with all types of anterior teeth (Table 1).

Table 1. Mean \pm standard deviation values of buccal bone thickness of related teeth at selected levels $(\mathrm{mm})$

\begin{tabular}{|l|l|l|l|l|}
\hline Tooth type & $\mathrm{N}$ & $\begin{array}{l}\text { At the crest } \\
\text { level }\end{array}$ & $\begin{array}{l}\text { At 1 mm } \\
\text { apical from } \\
\text { the crest } \\
\text { level }\end{array}$ & $\begin{array}{l}\text { At } 2 \mathrm{~mm} \\
\text { apical from } \\
\text { the crest } \\
\text { level }\end{array}$ \\
\hline $\begin{array}{l}\text { Right } \\
\text { central }\end{array}$ & 62 & $0.69 \pm 0.16$ & $0.74 \pm 0.18$ & $0.76 \pm 0.21$ \\
\hline $\begin{array}{l}\text { Right } \\
\text { lateral }\end{array}$ & 62 & $0.74 \pm 0.19$ & $0.81 \pm 0.23$ & $0.85 \pm 0.29$ \\
\hline $\begin{array}{l}\text { Right } \\
\text { canine }\end{array}$ & 62 & $0.97 \pm 0.26$ & $1.04 \pm 0.30$ & $1.06 \pm 0.35$ \\
\hline
\end{tabular}

No significant effects of gender $(\mathrm{p}=0.483$, $\mathrm{p}=0.988, \mathrm{p}=0.905$, respectively $)$ and age $(\mathrm{p}=0.838$, $\mathrm{p}=0.382, \mathrm{p}=0.953$, respectively) were observed on the buccal bone thickness of the central incisors, lateral incisors, and canine teeth (Table 2, 3). In regards to the intra-rater reliability, ICC values were above 0.80 and there was good reliability between repeated measurements.

Table 2. Comparison of mean buccal bone thickness according to gender (mm)

\begin{tabular}{|l|l|l|l|}
\hline \multirow{2}{*}{ Tooth type } & Gender & Mean \pm SD & $\begin{array}{l}\text { T test } \\
(\mathrm{p} \text { value })\end{array}$ \\
\hline \multirow{2}{*}{ Right central } & Male & $0.71 \pm 0.17$ & \multirow{2}{*}{0.483} \\
\cline { 2 - 3 } & Female & $0.74 \pm 0.17$ & \\
\hline \multirow{2}{*}{ Right lateral } & Male & $0.80 \pm 0.23$ & \multirow{2}{*}{0.988} \\
\cline { 2 - 3 } & Female & $0.80 \pm 0.22$ & \\
\hline \multirow{2}{*}{ Right canine } & Male & $1.02 \pm 0.28$ & \multirow{2}{*}{0.905} \\
\cline { 2 - 3 } & Female & $1.03 \pm 0.29$ & \\
\hline
\end{tabular}

SD: Standard deviation

Table 3. Comparison of mean buccal bone thickness of teeth according to age groups (mm)

\begin{tabular}{|c|c|c|c|}
\hline Tooth type & $\begin{array}{c}\text { Group } \\
\text { (Age range) }\end{array}$ & Mean \pm SD & $\begin{array}{c}\text { ANOVA test (p } \\
\text { value) }\end{array}$ \\
\hline \multirow{4}{*}{ Right central } & $19-29$ & $0.75 \pm 0.14$ & \multirow{2}{*}{0.838} \\
\cline { 2 - 3 } & $30-49$ & $0.72 \pm 0.20$ & \multirow{2}{*}{0.29} \\
\cline { 2 - 3 } & $50-60$ & $0.71 \pm 0.16$ & \\
\hline \multirow{3}{*}{ Right lateral } & $19-29$ & $0.78 \pm 0.22$ & \multirow{2}{*}{0.382} \\
\cline { 2 - 3 } & $30-49$ & $0.78 \pm 0.24$ & \multirow{2}{*}{0.953} \\
\cline { 2 - 3 } & $50-60$ & $0.88 \pm 0.21$ & \\
\hline \multirow{3}{*}{ Right canine } & $19-29$ & $1.03 \pm 0.33$ & \multirow{2}{*}{$0.92 \pm 0.28$} \\
\cline { 2 - 3 } & $30-49$ & $1.02 \pm 0.22$ & \\
\cline { 2 - 3 } & $50-60$ & $1 \pm 0.22$ \\
\hline
\end{tabular}

SD: Standard deviation 


\section{DISCUSSION}

Sensitive measurements are of paramount importance in the anterior dental arc, where aesthetic considerations are the primary concern apparently during the follow-up period after periodontal therapies. Therefore, several studies have investigated the mean values of several parameters associated with the alveolar crest and gingiva in the search for obtaining precise conclusions. ${ }^{10-12}$ Sagittal sections of CBCT images were used in several studies ${ }^{8,9,10}$ similar to that of our study.

Kim et $a .^{3}$ measured mean buccal bone thicknesses in the central incisor, lateral incisor, and canine regions as $0.86,0.83,0.90 \mathrm{~mm}$ respectively. Younes et al. ${ }^{13}$ performed the measurements in the same regions, reporting the respective mean values as $1.07,1.16$, and 0.98 $\mathrm{mm}$. Esfahanizadeh et al. ${ }^{14}$ measured the mean bone thickness as $0.72,0.70$, and $0.66 \mathrm{~mm}$ respectively in the same regions. In this present study, mean thickness values were found to be $0.73,0.80$, and $1.02 \mathrm{~mm}$, respectively. It is observed that there are discrepancies between the results of the studies. These observed discrepancies may be associated with ethnical differences, the use of different methodologies, and variations in teeth positioning. ${ }^{15}$

We found that the mean bone layer thickness increased towards the apical region at the buccal aspects of each tooth in our study but a few studies reported it decreasing towards the apical region. ${ }^{3,16}$ However, another study reported similar results to those of our study, finding that the buccal bone thickness of maxillary incisors increased gradually towards the apices. ${ }^{17}$ These results show that the nature of bone thickness, whether increasing or decreasing towards the apex, has not been clearly established yet.

Morais et al..$^{18}$ measured the bone thickness and bone height of the maxillary central incisors in 22 patients before and after orthodontic therapy. The thickness of the bone layers was measured at $3 \mathrm{~mm}$ and $6 \mathrm{~mm}$ apical from the crest level. The pre-treatment values were reported as 1 $\mathrm{mm}$ and $1.1 \mathrm{~mm}$, and the post-treatment values were $0.8 \mathrm{~mm}$ and $1 \mathrm{~mm}$, respectively. Comparison of the pre-treatment and post-treatment values demonstrated that although the quantified bone loss was different significantly at $3 \mathrm{~mm}$ apical from the crest, no significant differences were observed at $6 \mathrm{~mm}$ apical from the crest.

Crespi et al. ${ }^{19}$ placed 96 implants immediately into fresh sockets in the anterior maxillary region. Patients were divided into two groups as the ones with a bone thickness of $>1 \mathrm{~mm}$ and the ones with a bone thickness of $\leq 1 \mathrm{~mm}$. The degree of bone loss was followed up in both groups at the end of treatment with CBCT images taken before the tooth extraction and the one taken 3 years later. The quantity of bone loss was reported to be significantly different when the measured values in these two specified time points were compared. However, the degree of bone loss did not differ significantly between the two patient groups in the follow-up period. One may argue that the amount of bone loss associated with implanting is not related to the measured bone thickness before tooth extraction.

Adigüzel et al. ${ }^{20}$ measured the buccal bone thickness of 451 maxillary premolar and molar teeth using CBCT and analyzed the relationship of age and gender to buccal bone thickness. The thinnest bone region was $2.11 \mathrm{~mm}$ in females and $2.02 \mathrm{~mm}$ in males. The thickest bone region was 9.87 in females and $10.71 \mathrm{~mm}$ in males. In contrast to our study, that study found that age and gender variables were significantly associated with the buccal bone thickness in the maxilla. Therefore, it can be suggested that age and gender may affect buccal bone thickness in the anterior and posterior regions differently.

There should be a minimum of $2 \mathrm{~mm}$ buccal bone thickness to achieve satisfying results in implant therapy to be performed in the anterior region. ${ }^{21,22}$ Khoury et al. ${ }^{16}$ reported that a $2 \mathrm{~mm}$ thickness was found in $11 \%$ of the patients in the buccal bone $4 \mathrm{~mm}$ apical to alveolar crest. Another study observed buccal bone thicknesses of more than $2 \mathrm{~mm}$ at distances $1,2,3,4$, and 5 $\mathrm{mm}$ apical to the alveolar crest level in the respective ratios of $0 \%, 0.5 \%, 1.5 \%, 2 \%, 2.5 \%$, and $3 \%{ }^{23}$ A study investigated buccal bone 
thickness on 73 patients and reported that no values over $2 \mathrm{~mm}$ bone thickness were recorded. ${ }^{8}$ In our study, at the crest level and $1 \mathrm{~mm}$ apical to the crest level, we found no values exceeding 2 $\mathrm{mm}$ bone thickness. However, at $3 \mathrm{~mm}$ apical to the crest level, we observed a $0.54 \%$ percent rate of bone thickness values exceeding $2 \mathrm{~mm}$.

Fuentes et $a l .^{24}$ investigated buccal bone thickness of the anterior teeth, reporting that bone thickness of the right incisors did not differ by the age and gender; however, the buccal thickness of the left incisors differed significantly by these variables. Even in the same patients in that study, the buccal bone thickness of right and left teeth were affected differently by the age and gender, therefore, it can be suggested that gender and age are not predictors for buccal bone thickness.

\section{CONCLUSIONS}

In the literature, it is reported that a $2 \mathrm{~mm}$ bone thickness in the anterior region is essential for a successful aesthetic implant therapy. This was observed to an extent in our study, too. Age and gender factors are not predictors to provide insight into the existing buccal bone thickness for planning an implant therapy. In conclusion, CBCT should be used for a better three-dimensional understanding of the implant site before starting the therapy, especially when the crest dimensions are not precisely known in the anterior region.

\section{ACKNOWLEDGEMENTS}

None

\section{CONFLICTS OF INTEREST}

None

\section{Anterior Maksilladaki Bukkal Kemik Kalınlı̆̆ının \\ Değerlendirilmesi: Konik Işınlı Bilgisayarlı Tomografi Çalışması}

\section{$\ddot{O} Z$}

Amaçlar: Farklı yaş gruplarındaki ve cinsiyetteki hastaların bukkal kemik kalınlıklarının konik ışınlı bilgisayarl tomografi (KIBT) kullanılarak değerlendirilmesi amaçlanmıştır. Gereç ve Yöntemler: Çalışmamıza anterior 186 diş ve 62 hastanın KIBT görüntüleri dahil edilmiştir. Kret seviyesindeki, kret seviyesinden 1 ve $2 \mathrm{~mm}$ apikaldeki bukkal kemik kalınlıkları ölçülmüşü̈r. Elde edilen veriler T testi ve One-way ANOVA testi kullanılarak analiz edilmiştir. Bulgular: Anterior dişlerdeki bukkal kemik kalınlığına yaş gruplarl ve cinsiyetin anlamlı bir etkisinin olmadı $\breve{g}$ anlaşılmıştır ( $p>0,05)$. En yüksek ortalama bukkal kemik kalınlı̆̆ să̆ kanin bölgesinde 1,91 mm, en düşük ortalama bukkal kemik kalınlığl ise $0,35 \mathrm{~mm}$ değerinde să̆ lateral kesici bölgesinde ölçülmüştür. Sonuçlar: Sonuçlara göre; her üç diş tipinde de ortalama bukkal kemik kalınlı̆̆ apikal bölgeye doğru artış göstermiştir. Maksiller bukkal kemik kalınlı̆̆ını KIBT ile ölçerek dental implant planlamasında ve diğer cerrahi operasyonlar hakkında öngörü sahibi olmak daha kolay olacaktır ve aynı zamanda kesin ölçüm değerleri sağlanabilecektir. Anahtar Kelimeler: Alveoler kemik kaybı, konik ışınlı bilgisayarlı tomografi, maksilla

\section{REFERENCES}

1. Coots BK. Alveolar bone grafting: past, present, and new horizons. Semin Plast Surg 2012;26:178-183.

2. Garg AK. Bone: Biology, Harvesting and Grafting for Dental Implants. Chicago: Quintessence 2004:171211.

3. Kim YJ, Park JM, Kim S, Koo KT, Seol YJ, Lee YM, Rhyu IC, Ku Y. New method of assessing the relationship between buccal bone thickness and gingival thickness. J Periodontal Implant Sci 2016;46:372-381.

4. Deshpande S, Deshmukh J, Deshpande S, Khatri R, Deshpande S. Vertical and horizontal ridge augmentation in anterior maxilla using autograft, xenograft and titanium mesh with simultaneous placement of endosseous implants. J Indian Soc Periodontol 2014;18:661.

5. Poli PP, Beretta $M$, Cicciù $M$, Maiorana $C$. Alveolar ridge augmentation with titanium mesh. A retrospective clinical study. Open Dent J 2014;8:148.

6. Scarfe WC, Farman AG . What is cone-beam CT and how does it work? Dent Clin North Am 2008;52:707-730.

7. Tan WL, Wong TL, Wong MC, Lang NP. A systematic review of post-extractional alveolar hard and soft tissue dimensional changes in humans. Clin Oral Implants Res 2012;23:1-21.

8. El Nahass H, N. Naiem S. Analysis of the dimensions of the labial bone wall in the anterior maxilla: a cone-beam computed tomography study. Clin Oral Implants Res 2015;26:e57-e61.

9. Arora H, Ivanovski S. Correlation between preoperative buccal bone thickness and soft tissue changes around immediately placed and restored implants in the maxillary anterior region: A 2-year prospective study. Clin Oral Implants Res 2017;28:1188-1194. 
10. Januário AL, Duarte WR, Barriviera M, Mesti JC, Araújo MG, Lindhe J. Dimension of the facial bone wall in the anterior maxilla: a cone-beam computed tomography study. Clin Oral Implants Res 2011;22:1168-1171.

11. La Rocca AP, Alemany AS, Levi Jr P, Juan MV, Molina JN, Weisgold AS. Anterior maxillary and mandibular biotype: relationship between gingival thickness and width with respect to underlying bone thickness. Implant Dent 2012;21:507-515.

12. Nikiforidou M, Tsalikis L, Angelopoulos C, Menexes G, Vouros I, Konstantinides A. Classification of periodontal biotypes with the use of CBCT. A crosssectional study. Clin Oral Investig 2016;20:2061-2071.

13. Younes F, Eghbali A, Raes M, De Bruyckere T, Cosyn J, De Bruyn H. Relationship between buccal bone and gingival thickness revisited using noninvasive registration methods. Clin Oral Implants Res 2016;27:523-528.

14. Esfahanizadeh N, Daneshparvar N, Askarpour F, Akhoundi N, Panjnoush M. Correlation Between Bone and Soft Tissue Thickness in Maxillary Anterior Teeth. J Dent (Tehran) 2016;13:302-308.

15. Fu JH, Lee A, Wang HL. Influence of tissue biotype on implant esthetics. Int $\mathbf{J}$ Oral Maxillofac Implants 2011;26:499-508.

16. Khoury J, Ghosn N, Mokbel N, Naaman N. Buccal Bone Thickness Overlying Maxillary Anterior Teeth: A Clinical and Radiographic Prospective Human Study. Implant Dent 2016;25:525-531.

17. Zhang CY, DeBaz C, Bhandal G, Alli F, Francisco MCB, Thacker HL, Palomo JM, Palomo L. Buccal bone thickness in the esthetic zone of postmenopausal women: A CBCT analysis. Implant Dent 2016;25:478484.
18. Morais JF, Melsen B, de Freitas KMS, Castello Branco N, Garib DG, Cattaneo PM. Evaluation of maxillary buccal alveolar bone before and after orthodontic alignment without extractions: A cone beam computed tomographic study. Angle Orthod 2018;88:748-756.

19. Crespi R, Cappare P, Gastaldi G, Gherlone EF. Buccal-Lingual Bone Remodeling in Immediately Loaded Fresh Socket Implants: A Cone Beam Computed Tomography Study. Int J Periodontics Restorative Dent 2018;35:43-49.

20. Adiguzel O, Aktuna Belgin C, Falakaloglu S, Cangul S, Akkus Z. Maxillary Cortical Bone Thickness in a South-Eastern Anatolian Population: A ConeBeam Computed Tomography Study. Med Sci Monit 2017;23:5812-5817.

21. Spray JR, Black CG, Morris HF, Ochi S. The influence of bone thickness on facial marginal bone response: stage 1 placement through stage 2 uncovering. Ann Periodontol 2000;5:119-128.

22. Fu JH, Yeh CY, Chan HL, Tatarakis N, Leong DJ, Wang HL. Tissue biotype and its relation to the underlying bone morphology. J Periodontol 2010;81:569-574.

23. Ghassemian M, Nowzari H, Lajolo C, Verdugo F, Pirronti T, D'addona A. The thickness of facial alveolar bone overlying healthy maxillary anterior teeth. J Periodontol 2012;83:187-197.

24. Fuentes R, Flores T, Navarro P, Salamanca C, Beltrán V, Borie E. Assessment of buccal bone thickness of aesthetic maxillary region: a cone-beam computed tomography study. J Periodontal Implant Sci 2015;45:162-168. 